Центр воєнно-стратегічних досліджень Національного університету оборони України імені Івана Черняховського, Київ

\title{
Застосування технології контролінгу для управління кар'єрою військовослужбовців
}

Резюме. Розглянуто питання обгрунтування пропозицій раціонального напряму застосування інформаційних технологій щодо автоматизації процесів управління кар'єрою військовослужбовців шляхом розроблення та впровадження технологій контролінгу.

Ключові слова: контролінг, управління кар'єрою, персонал Збройних Сил.

Постановка проблеми. Однією з умов ефективного використання збройних сил (3С) $\epsilon$ досягнення переваги перед ЗС ймовірного противника, зокрема і у сфері формування кадрового потенціалу. Кадровий потениіал це можливість ЗС виконувати свої основні функції (захист суверенітету, відсіч агресіі), яка заснована на певних якостях персоналу 3C.

Зміни, які відбуваються в ЗС України, обумовлені воєнною політикою України, суттю іiі державної кадрової політики та завданнями розвитку ЗС України. На етапі проведення у ЗС України оборонної реформи існує низка важливих завдань зі створення сучасної системи кадрового менеджменту.

Планом дій щодо впровадження оборонної реформи у 2016-2020 роках (Дорожня карта оборонної реформи), зокрема передбачено професіоналізацію сил оборони та створення необхідного військового резерву - стратегічна ціль № 5. Отже, сучасний стан військової кадрової політики в ЗС України потребує більш глибокого розуміння системи управління кар'єрою військовослужбовців для максимального підвищення кількості посад обійманих компетентними та високопрофесійними командирами i начальниками на тлі загострення політичного протистояння та збройної агресії проти нашої держави.

Використання новітніх технологій у процесі управління персоналом ЗС України, перехід від номенклатурної системи до системи всебічного кадрового забезпечення щодо прийняття кадрових рішень, передбачає перерозподіл завдань і функцій між органами військового управління, кадровими органами.

Це мотивує необхідність удосконалення технологій управління кар'єрою особового складу, насамперед, технологій призначення військовослужбовців на посади залежно від завдань підрозділів, військових частин, від планів подальшого їх використання у процесі проходження військової служби за контрактом.

Аналіз останніх досліджень i публікацій. Аналіз сучасного досвіду будівництва 3С провідних державчленів НАТО свідчить про те, що підтримувати необхідний рівень професіоналізму військовослужбовців можливо лише в умовах наявності професійної армії. Підходи до управління кар'єрою персоналу у провідних країнах світу HR-менеджерами розглядається за методологією управління талантами, що становить комплекс взаємозв'язаних підсистем, спрямованих на набір, навчання та розвиток, мотивування i утримання кваліфікованих співробітників. Сучасна практика управління персоналом великих корпорацій показує, що інвестування ресурсів підприємства у розвиток внутрішнього кадрового резерву перспективніша перед зовнішнім. Підвищення професійності, збереження спадковості та корпоративної етики організації, створення привабливих умов для кар'єрного зростання персоналу дають змогу установам (відомствам) здійснювати ефективніше функціонування. Збалансованість та ефективність управління кар'єрою персоналу забезпечується завдяки використанню інформаційних технологій на основі контролінгу та систем підтримки прийняття рішень [1, 2].

Кадровою стратегією в життєдіяльності ЗС України на перспективу визначено: побудова нової системи кадрового менеджменту централізованого типу, 
професіоналізація війська, персоналізація кадрової професійної діяльності з персоналом, прогнозування та супроводження кар'єри військовослужбовців. Вирішення означених завдань можливе завдяки застосуванню інструментів стратегічного управління, одним 3 яких є технологія контролінгу.

\section{Технологія контролінгу}

найважливіший елемент сучасного менеджменту, дієвий інструмент концепції ефективного стратегічного управління для досягнення стабільного існування i функціонування підприємства, відомства (у цій статті 3С України). Контролінг управління персоналом - це комплекс заходів, спрямованих на координацію управління i контроль його ефективності завдяки інформаційно-аналітичній підтримці процесів прийняття рішень 3 управління збройними силами загалом і управління кар'єрою військовослужбовців зокрема.

Питання стратегічного менеджменту та ефективного управління організацією, досягнення цілей управління завдяки використанню збалансованих показників, їx контроль для гнучкого та раціонального використання ресурсів, висвітлені у роботах $[3,4]$.

У роботі [3] розглядаються основні аспекти застосування аудиту та кадрового контролінгу, як основи забезпечення координації функцій управління персоналом, своєчасного виявлення недоліків i ризиків кадрової роботи, їх врахування у плануванні та виробленні управлінських рішень.

Необхідність впровадження технологій кадрового контролінгу, основні підходи, структуру та зміст розглянуто у роботі [3], у якій автором запропоновано організаційну модель кадрового контролінгу, модульні блоки якої залежать від чинників (галузі, розміру організації, організаційної структури, стратегічних цілей і завдань тощо).

Використання системи збалансованих показників (СЗП) як основи функціонування технології контролінгу комерційних і державних організацій висвітлено у роботі [4]. Особливої уваги заслуговують причини, які спонукали застосуванню СЗП у сфері захисту національних інтересів, зміцнення миру та міжнародної безпеки на прикладі ЗС США та Великобританії, де головний пріоритет підвищення рівня професіоналізації та мотивації особового складу.

Особливості розроблення та використання ключових показників ефективності у системі кадрового менеджменту збройних сил на основі концепції контролінгу висвітлено у роботі [5], у якій запропоновано підходи до розроблення та впровадження у діяльність кадрових органів ключових показників ефективності для оцінювання складових елементів системи кадрового менеджменту відповідно до планування на основі спроможностей.

Основне завдання у створенні сучасної системи кадрового менеджменту полягає в отриманні цілісної картини стратегічної готовності та інформованості керівництва про боєготовність арміі у сьогоденні та майбутньому, головним критерієм якої $\epsilon$ підвищення ступеня професіоналізації персоналу. Дієвим механізмом цих процесів $є$ впровадження технологій контролінгу iз застосуванням системи ключових показників для ефективного управління кар'єрою військовослужбовців. Проте аналіз наукової літератури свідчить про приділення недостатньої уваги порушеному питанню, що може призвести до уповільнення процесів професійного зростання, та наближення 3С України до стандартів НАТО.

Мета статті - обгрунтування показників ефективності управління кар'єрою військовослужбовців за відповідними групами критеріїв.

Виклад основного матеріалу. Процеси управління кар'єрою військовослужбовців збройних сил стосовно аналогічних процесів у цивільному секторі, містять схожу функціональну направленість, проте існує низка характерних особливостей, які значно їх відрізняють.

По-перше, у військовій організаційній структурі існує чітко визначена номенклатура посад, розподілена за профілями службової діяльності. Вимоги посади передбачають набір кількісних i якісних критеріїв до кандидата, його рангу та набутого досвіду, що унеможливлює призначення на посаду “зі сторони”. Кар'єрне зростання військовослужбовців відбувається “знизу вгору”. Отже робочі місця в ЗС $\epsilon$ стабільнішими, але не такими гнучкими, як у цивільній організації.

По-друге, набір персоналу у ЗС здійснюється лише через проведення необхідних процедур, які включають обов'язкову базову підготовку кандидатів. Основним джерелом вербування первинного персоналу до ЗС є зовнішні трудові ресурси.

По-третє, результати системи оцінювання ефективності персоналу у військовій організації мають дещо інший 
вплив, як порівняти 3 цивільними організаціями, у яких найбільший пріоритет приділяється отриманню максимального прибутку.

Контролінг являє собою міжфункціональний напрям управлінської діяльності, який завдяки цілеспрямованим збору, обробці та альтернативному інтерпретуванню отриманої інформації у вигляді ключових показників ефективності, допомагає під час прийняття управлінських рішень, головною метою яких $є$ досягнення оптимальної узгодженості рівня розвитку та прибутковості (якості надання послуг) підприємства (військового відомства).

Контролінг у кадровій сфері дає змогу впливати на процеси планування персоналу відповідно до цілей організації, підвищує ефективність використання персоналу, оцінюючи витрати на персонал і можливості отримання організацією максимального прибутку, визначає задіяння необхідних процесів щодо мотивації персоналу на основі, наприклад, диференційної системи винагород і витрат на його навчання і розвиток.

Протягом останніх років у МО України значна увага приділяється автоматизації процесів управління особовим складом.

Аналіз стану автоматизації показує, що на поточний момент можливості інформаційно-аналітичної системи (IAC) "Персонал" дають змогу виконувати основний перелік процесів управління кар'єрою військовослужбовців, визначених у нормативно-правових документах [7, 8]. Проте існує низка нереалізованих функцій у системі, можливості яких сприяли б у досягненні оперативних цілей та завдань зі створення сучасної системи кадрового менеджменту, до яких відноситься:

оцінювання ефективності управління кар'єрою військовослужбовців;

автоматизації процесів прийняття обгрунтованих кадрових рішень, 3 урахуванням впливу на систему управління зовнішніх і внутрішніх чинників.

Зовнішній вплив на систему управління кар'єрою військовослужбовців обумовлене такими чинниками:

ситуація на ринку праці (наявність робочих місць, привабливі умови праці);

стратегія військової кадрової політики, вимоги нормативно-правових документів щодо проходження військової служби;

вимоги до посади (перелік вимог, компетенцій та особистих якостей, які потрібен мати військовослужбовець); умови проходження служби (соціальні, фізико-географічні, культурні, побутові та інші);

забезпечення військовослужбовця під час проходження служби (фінансове, комунально-експлуатаційне, речове та інші); профіль діяльності (командний, штабний, технічний, науковий, педагогічний та інші).

Розвиток кар'єри військовослужбовця залежить від внутрішніх чинників:

професійна компетентність [6, 7], яка включає теоретичну, практичну, особистісну та психологічну підготовленість; стан здоров'я; вік військовослужбовця.

У теорії управління вважають, що система управління створюється для досягнення суб'єктом управління поставлених цілей. Розглядаючи систему управління кар'єрою військовослужбовців 3 огляду на системний підхід, можна виділити основні функції, до яких належать: аналіз, планування, контроль, організація, регулювання (рис. 1).

Головним пріоритетом цілей та завдань системи управління кар'єрою, визначених у [8], є зростання ступеня професіоналізації персоналу ЗС України, визначальними чинниками якого становлять досягнення організаційного, економічного та соціального ефектів - ключових факторів успіху.

Організачійні ефекти полягають у: скороченні часу прийняття рішень на всіх рівнях управління організаційною ієрархією; якості укомплектованості підрозділів підготовленим особовим складом, обгрунтованості та об'єктивності кадрових рішень; оперативної звітності до вищих органів управління відповідно до законодавчих і нормативних вимог.

Економічні ефекти полягають у: збалансованості витрат на утримання персоналу за умови його раціонального використання; збалансованості та прогнозованості витрат на розвиток персоналу за окремо визначений період; підвищенні якості та продуктивності військової служби від використання на ключових посадах професійно підготовлених військовослужбовців; збалансованості та прогнозованості витрат на ресурсне забезпечення персоналу відповідно до стандартів НАТО за окремо визначений період. 


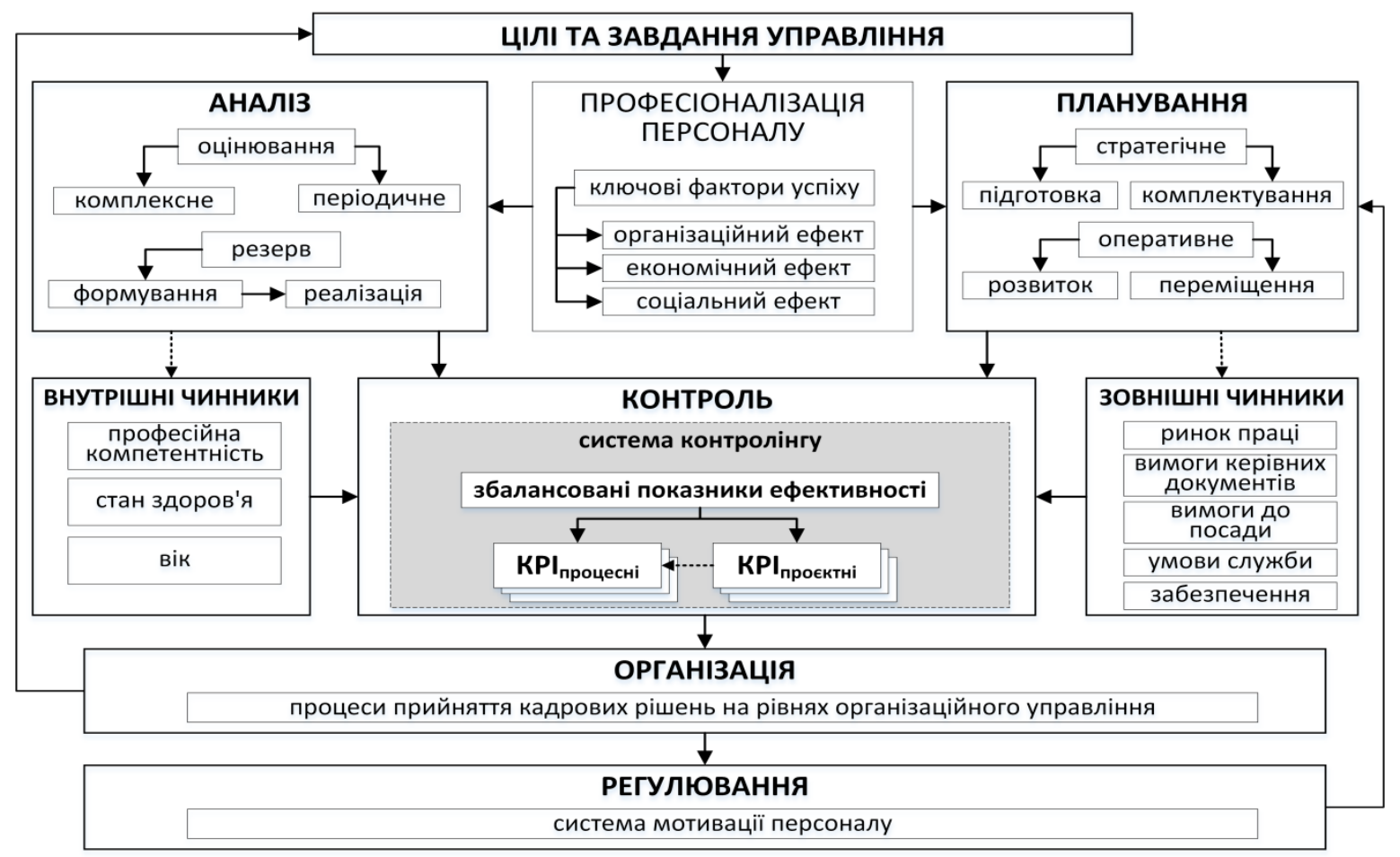

Рис. 1. Функції системи управління кар'єрою

Соиіальні ефекти полягають у: підвищенні ефективності щодо реалізації особистої службової кар'єри персоналу відповідно до запланованої службами персоналу індивідуальної програми розвитку; підвищенні ступеня реалізації особистих потреб і вподобань персоналом; підвищенні ефективності реалізації Резерву і просування на вищі посади найперспективніших військовослужбовців; підвищенні мотивації персоналу до виконання службових обов'язків, захисту територіальної цілісності та недоторканості України.

Досягнення ключових факторів успіху залежить від якості та повноти вжитих заходів iз планування на стратегічному та оперативному рівнях управління, завданням яких $\epsilon$ планування потреби у людських pecypcax для підготовки та комплектування збройних сил відповідно до імовірної структури та сценаріїв застосування. До оперативних заходів відноситься планування типових алгоритмів управління кар'єрою, як основи для планування індивідуальної кар'єри військовослужбовців, а також планування переміщення персоналу на посадах.

Аналіз ступеня відповідності персоналу визначеним посадовим функціям здійснюється через комплексне оцінювання та періодичне атестування службової діяльності, на основі яких реалізується план переміщення військовослужбовців на посадах, зокрема i формування кадрового резерву кандидатів для призначення на вищі посади.

Зважаючи на світовий досвід [9], для підвищення ефективності використання кадрового ресурсу та оцінювання якості управління кар'єрою військовослужбовців, основні зусилля доцільно зосередити на дослідженні питань розроблення та впровадження інформаційних технологій контролінгу. Автоматизація процесів вимірювання відхилень фактичних кількісних і якісних показників системи управління від запланованих, підвищить ефективність функцій контролю системи управління кар'єрою, створюватиме підгрунтя для прийняття кадрових рішень.

Інформаційну технологію контролінгу пропонується побудувати завдяки впровадженню процесних i проєктних ключових показників ефективності (КРІ - Кеу Performance Indicator) за групами критеріїв організаційної, економічної та соціальної ефективності.

До групи критеріїв організаційної ефективності належать:

укомплектованість

підрозділів

підготовленим особовим складом;

раціональне використання професійних якостей персоналу;

оперативність реалізації кадрових рішень.

Критерій кожної групи включає декілька контрольованих показників. Кожний 
зі збалансованих ключових показників містить відповідні індекси:

$\boldsymbol{r}$-рівень організаційної ієрархії (військового управління), де: $r \in R, \quad(r=\overline{1, R}), R-$ множина рівнів;

$\boldsymbol{i}$-категорія персоналу за військовим званням (рядовий, сержантський, старшинський, молодший, старший або вищий офіцерський склад), де: $i \in I, \quad(i=\overline{1, I}), \quad I$ - множина категорій персоналу;

$\boldsymbol{j}$-профіль службової діяльності (групи військово-облікової спеціальності), де: $j \in J, \quad(j=\overline{1, J}), J$ - множина профілів;

$\boldsymbol{t}$ - дата здійснення контролю показника.

Так, наприклад, критерій 3 оцінки укомплектованості підрозділів підготовленим особовим складом включає показники:

1. Показник $k_{i j r}^{y \kappa} \quad$ укомплектованості персоналом:

$$
k_{i j r}^{y \kappa}(t)=\frac{P_{i j r}(t)}{S_{j r}(t)} \times 100 \%,
$$

де $P_{i j r}$ - кількість

підготовлених

військовослужбовців $i$-ї категорії персоналу, $j$-го профілю службової діяльності, $r$-го рівня управління;

$S_{j r}$ - кількість штатних посад, які обіймають військовослужбовці, відповідно до $j$-го профілю службової діяльності, $r$-го рівня управління.

Показник $k_{i j r}^{y \kappa}$ надає можливості службам управління персоналом $r$-го рівня управління в межах своїх повноважень здійснювати контроль стану укомплектованості підготовленим особовим складом за $i$-ту категорію, відповідно до $j$-го профілю службової діяльності, в кінці та у процесі проведення організаційно-штатних заходів.

2. Показник $k_{i j r}^{\mu} \quad$ надходження персоналу:

$$
k_{i j r}^{H}(t)=\frac{P_{i j r}^{H}(t)}{S_{j r}^{\text {sak }}(t)} \times 100 \%,
$$

де $P_{i j r}^{H}$ - кількість надходження персоналу до

3С України з числа громадян України (призовники, резервісти, військовослужбовці запасу, випускники військових навчальних закладів та інші) $i$-ї категорії персоналу, $j$-го профілю службової діяльності, $r$-го рівня управління;

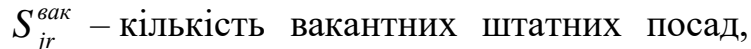
які потребують призначення, відповідно до $j$-го профілю службової діяльності, $r$-го рівня управління.

Показник $k_{i j r}^{H}$ надає можливості службам управління персоналом $r$-го рівня управління в межах своїх повноважень здійснювати контроль стану надходження персоналу до ЗС України з числа громадян України за $i$-ту категорію, відповідно до $j$-го профілю службової діяльності, в кінці та у процесі проведення організаційно-штатних заходів. Відповідно до значення показника $k_{i j r}^{H}$ здійснювати корегування його розподілу та визначення потреби, під час планування на майбутні періоди.

3. Показник $k_{i j r}^{n l}$ плинності кадрів:

$$
k_{i j r}^{n n}(t)=\frac{P_{i j r}^{3 \beta}(t)}{P_{i j r}(t)} \times 100 \%,
$$

де $P_{i j r}^{36}$ - кількість звільнених

військовослужбовців із лав ЗС України $i$-ї категорії персоналу, $j$-го профілю службової діяльності, $r$-го рівня управління організаційною ієрархією.

Показник $k_{i j r}^{n \pi}$ надає можливості службам управління персоналом $r$-го рівня управління в межах своїх повноважень здійснювати контроль стану плинності кадрів. Збільшення значення цього показника свідчить про відтік спеціалістів $i$-ї категорії, $j$ го профілю, що $\epsilon$ передумовою для дослідження причин цього явища. Нею може бути низька конкурентна спроможність посади за профілем діяльності, порівняно 3 ринком праці у цивільному секторі, або незадовільні соціально-побутові умови для військовослужбовців і членів їх родин. Отже, збільшення значення показника $k_{i j r}^{n n}$ має супроводжуватись 3 активізацією мотиваційних заходів персоналу.

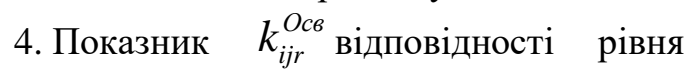
отриманої освіти:

$$
k_{i j r}^{O c s}(t)=\frac{P_{i j r}^{O c s}(t)}{S_{j r}^{\text {Busu }}(t)} \times 100 \%,
$$

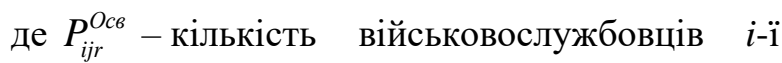
категорії персоналу, $j$-го профілю службової діяльності, $r$-го рівня управління, які за результатами 
комплексного оцінювання включені до Резерву кандидатів призначення на вищі посади, і рівень їх освіти відповідає вимогам цієї посади;

$S_{j r}^{\text {Buм }}-$ вимоги до вищої посади, відповідно до профілю компетенцій паспорту військової посади, $j$-го профілю службової діяльності, $r$-го рівня управління.

Показник $k_{i j r}^{O c s}$ дає змогу службам управління персоналом $r$-го рівня управління в межах своїх повноважень здійснювати контроль стану відповідності рівня освіти військовослужбовців, зарахованих до Резерву кандидатів призначення на вищі посади $i$-ї категорії персоналу, j-го профілю службової діяльності. Значення цього показника створює підгрунтя щодо планування чисельності слухачів для здобуття необхідного рівня освіти, відповідно до $j$-го профілю службової діяльності.

5. Показник $k_{i j r}^{\text {Навч }}$ навченості персоналу:

$$
k_{i j r}^{\text {Навч }}(t)=\frac{P_{i j r}^{\text {Навч }}(t)}{P_{i j r}(t)} \times 100 \%,
$$

де $P_{i j r}^{\text {Навч }}$ - кількість військовослужбовців, які є носіями унікальних знань, службового (бойового) досвіду виконання посадових обов'язків $i$-ї категорії персоналу, $j$-го профілю службової діяльності, $r$-го рівня управління;

Показник $k_{i j r}^{\text {Навч }}$ дає змогу службам управління персоналом $r$-го рівня управління в межах своїх повноважень здійснювати контроль ступеню професіоналізації персоналу $i$-ї категорії персоналу, $j$-го профілю службової діяльності. Значення цього показника створює підгрунтя щодо планування чисельності військовослужбовців для проходження курсів підвищення кваліфікації, участі у міжнародних навчаннях і миротворчих операціях, інших заходах 3 розвитку персоналу, у яких важливим компонентом $\epsilon$ передавання досвіду та наступництво.
6. Показник

$$
k_{i r}^{4}
$$
частки

військовослужбовців категорій солдатського i сержантського, офіцерського складу i курсантів до загальної чисельності військовослужбовців:

$$
k_{i r}^{u}(t)=\frac{P_{i r}(t)}{\sum_{i=1}^{I} P_{i r}(t)} \times 100 \%,
$$

де $P_{i r}$ - кількість військовослужбовців $i$-ї категорії персоналу, $r$-го рівня управління.

Показник $k_{i r}^{u}$ дає змогу службам управління персоналом $r$-го рівня управління в межах своїх повноважень здійснювати контроль щодо досягнення оптимального співвідношення показників [7] указаних категорій персоналу.

$$
\text { 7. Показник } k_{l r}^{4 O B У} \quad \text { частки }
$$

військовослужбовців, які перебувають на посадах з ШПК “майор”, “підполковник” i “полковник” в органах військового управління стратегічного, оперативного рівнів, ВВНЗ і військових наукових закладах.

$$
k_{l r}^{\text {чОВу }}(t)=\frac{P_{l r}(t)}{\sum_{i=1}^{I} P_{i r}(t)} \times 100 \%,
$$

де $P_{l r}$ - кількість військовослужбовців, які перебувають на $l$-х посадах, $r$-го рівня управління;

$L$-множина посад 3 ШПК "майор", "підполковник" і “полковник”, $l \in L, \quad(l=\overline{1, L})$

$P_{i r}$ - кількість військовослужбовців $i$-ї категорії персоналу, $r$-го рівня управління;

$t$-дата здійснення контролю показників може встановлюватись за рішеннями керівництва служб персоналу i охоплювати період, наприклад, щомісяця, щорічно або у разі службової необхідності.

Показник $k_{l r}^{4 O B у}$ дає змогу службам управління персоналом $r$-го рівня управління, в межах своїх повноважень здійснювати контроль щодо досягнення оптимального співвідношення показників [7], де персонал обіймає посади із вказаною штатно-посадовою категорією.

До групи критеріїв економічної ефективності належать:

критерії оцінки ресурсів на утримання персоналу (за видами забезпечення);

критерії оцінки ресурсів на утримання служб управління персоналом;

критерії оцінки ресурсів на розвиток персоналу. 
До групи критеріїв соціальної ефективності належать:

критерії оцінки ступеня очікування потреб і вподобань персоналу;

критерії оцінки ступеня реалізації індивідуального розвитку кар'єри персоналу;

критерії оцінки ступеня реалізації Резерву для просування на вищі посади;

критерії оцінки вжитих заходів, спрямованих на мотивацію персоналу.

Автоматизація процесів контролю оперативних цілей (короткострокових завдань) вирішується за допомогою розроблених процесних КРІ, зріз інформації за якими здійснюється на вимогу у будь-який момент часу. Контроль стратегічних цілей вирішується за допомогою проєктних КРІ, які надають інформацію про ступінь їх кінцевої реалізації відповідно до запланованих показників.

Упровадження системи контролінгу в автоматизовану систему управління персоналом (АСУП) на основі системи збалансованих процесних i проєктних показників ефективності, розподілених за рівнями управління організаційною ієрархією, дає змогу оцінювати вхідні дані у вигляді кількісних i якісних показників системи аналізу і планування, їх надійність і можливі ризики, вплив зовнішніх i внутрішніх чинників.

Також, існує необхідність накопичення вихідних даних KPI у сховищі даних для їх подальшої обробки в аналітичних додатках, створенні на їх основі вітрини даних та використовувати як вхідні дані для системи підтримки прийняття кадрових рішень посадовою особою.

Вітрина даних - інформаційний зріз сховища даних, що являє собою масив тематичної вузьконаправленої інформації у межах повноважень користувача (посадової особи). На основі вітрини даних розробляються інформаційні панелі даних для зручного відображення інформації, наприклад у вигляді: таблиці, датчиків, графіків, діаграм тощо.

Наведений у статті варіант використання перелічених компонентів функцій контролю в управлінні кар'єрою військовослужбовців потребує проведення грунтовних наукових досліджень, зв'язаних 3 розробленням:

критеріїв оцінки ефективності управління кар'єрою військовослужбовців; методики формування збалансованої системи показників на основі критеріїв оцінки ефективності системи управління кар'єрою; концептуальної моделі управління кар'єрою військовослужбовців ЗС України.

Необхідною умовою впровадження на практиці запропонованого варіанта застосування інформаційних технологій щодо автоматизації функцій контролю в управлінні кар'єрою військовослужбовців $\epsilon$ подальше розширення функціональних спроможностей (інформаційно-аналітичної системи (IAC) "Персонал". Напрями удосконалення полягають у розробленні спеціального програмного забезпечення на програмній платформі інформаційно-аналітичної системи, можливості якої забезпечать обробку, зберігання інформації та візуалізацію ступенів досягнення оперативних і стратегічних цілей за показниками ефективності функцій аналізу i планування системи управління із врахуванням впливу зовнішніх i внутрішніх чинників. Удосконалення IAC “Персонал” має передбачати створення нових автоматизованих робочих місць за рівнями управління організаційною структурою збройних сил, повнота та обсяг оброблюваної інформації яких відрізняється складом збалансованих показників ефективності у межах повноважень посадової особи органу управління.

Висновки. Сукупність викладених положень свідчить про актуальність досліджень інформаційних технологій контролінгу у галузі управління персоналом. Розв'язання цієї наукової задачі сприятиме створенню умов для гарантованого і якісного комплектування збройних сил особовим складом, спроможного виконувати завдання за призначенням. Раціональне використання потенціалу кожного військовослужбовця, створення чітких перспектив розвитку індивідуальної кар'єри виражене у поєднанні інтересів військового відомства та конкретної особи.

Подальші дослідження доцільно зосередити на формуванні кількісних показників економічної та соціальної ефективності управління кар'єрою персоналу 3С України, а також дослідженні питань побудови моделі підтримки прийняття кадрових рішень посадовою особою, на основі оптимізаційних і прогнозних математичних моделей.

СПИСОК ВИКОРИСТАНОЇ ЛІТЕРАТУРИ 
1. Винничук Р.О. Особливості навчання працівників у системі талант-менеджменту: світова практика та рекомендації // Науковий вісник Мукачівського державного університету. Економіка і суспільство. Мукачево, 2018. № 16. C. 647-653. URL: http://economyandsociety.in.ua/journal/16_ukr/98.p df.

2. Одегов Ю. Г., Никонова Т. В. Аудит и контроллинг персонала. Москва : Альфа-Пресс, 2006. $560 \mathrm{c}$.

3. Ценклер Н. І. Методичні підходи до формування моделі кадрового контролінгу // Науковий вісник Ужгородського університету. Економіка. Ужгород, 2015. № 1 (2). С. 269-272. URL: http://nbuv.gov.ua/UJRN/Nvuuec_2015_1\%282\%2 9_57 (дата звернення: 26.12.2019).

4. Каплан Р., Нортон Д. Стратегические карты. Трансформация нематериальных активов в материальные результаты. Москва : ОлимпБизнес, 2005. 512 c;

5. Рибидайло А. А., Прокопенко О. С., Турейчук А. М., Руденська Г. В. Ключові показники ефективності управління персоналом збройних сил. Збірник наукових пращь Центру воєнно-стратегічних досліджень Національного університету оборони України імені Івана Черняховського. Київ, 2019. № 1 (65). С. 65-74.
DOI: https://doi.org/10.33099/2304-2745/2019-165/65-74 (дата звернення: 27.12.2019).

6 Ягупов В. В. Методологические требования компетентностного подхода в профессиональном образовании. Вища освіти України: теоретичний i науково-методичний часопис. Київ, 2013. С. 82-85. URL: http://lib.iitta.gov.ua/10974/1/методол_треб_ комп_подх_Левшин.pdf (дата звернення: 04.01.2020).

7 Про затвердження Концепції військової кадрової політики у ЗС України на період до 2020 року : наказ Міністерства оборони України від 26.06.2017 p. № $342 . \quad$ URL: http://www.mil.gov.ua/diyalnist/kadrovapolitika/konczepcziya-kadrovoi-politiki-v-zbrojnihsilah-ukraini (дата звернення: 26.12.2019).

8. Смцов А. А., Вєтров В. I., Шпанчук Г.В. Технології кадрового менеджменту та їх застосування. Збірник наукових праць "Військова освіта" Національного університету оборони України імені Івана Черняховського. Київ, 2014. № 2 (30). С. 79-86.

9. Буцкой Г. В. Система управління військовим персоналом в збройних силах Словацької Республіки // Збірник наукових статей слухачів інституту державного військового управління Національного університету оборони України. Київ, 2010. С. 53-58.

Стаття надійшла до редакційної колегії 11.01.2020

\section{The use of Controlling technology to manage the careers of military personnel}

\section{Annotation}

The main task in creating a modern Personnel Management System is to obtain clear data on the readiness of the Armed Forces of Ukraine and to keep the military decision-makers informed about the combat readiness of the Armed Forces today and in the future. The main task of the Personnel Management System is to increase the level of professionalization of the military personnel. An effective mechanism for increasing the level of professionalization is the introduction of Controlling Technologies, which uses key indicators for effective career management. However, the analysis of scientific works shows that this issue is not given sufficient importance, and as a result, this can slow down the professional development of the Armed Forces and approximation to the standards of NATO member countries.

The purpose of the article is to substantiate the performance indicators of the Career Management System (CMS) for the relevant groups of criteria. The main priority of the objectives and tasks of the CMS is to increase the level of professionalization of Armed Forces personnel. The determining factors of CMS are the achievement of organizational, economic and social effects - key success factors.

A prerequisite for the implementation of the proposed option involves the use of Information Technology (IT) to automate relevant tasks. Currently, the capabilities of the Information and Analytical System (IAS) "Personnel" provide processing, storage, and visualization of data to achieve Operational and Strategic goals in terms of the effectiveness of the analysis and planning functions of the Management System, considering the influence of external and internal factors. But the CMS should continue to anticipate the further expansion of its capabilities. The areas of improvement are the further development of special software on the platform of the IAS "Personnel". Improvement of IAS "Personnel" should envisage the creation of new automated workplaces by the levels of management of the organizational structure, completeness, and volume of the processed information, and differ in the composition of balanced performance indicators.

Keywords: Controlling; Information Technology (IT), Career Management System (CMS); Armed Forces; Information and Analytical System (IAS) "Personnel". 